Hal : $11-13$

\title{
PENGARUH HANDS ON MINDS ON ACTIVITY TERHADAP HASIL BELAJAR SISWA MELALUI STRATEGI PEMBELAJARAN INKUIRI TERBIMBING PADA SMPS METHODIST TANJUNG MORAWA
}

\author{
Juliana Naftali Sitompul \\ STMIK Kaputama Binjai \\ Jl. Veteran N0. 4a-9a Binjai \\ joellyanna07@gmail.com
}

\begin{abstract}
Abstrak
Penelitian ini bertujuan untuk mengetahui pengaruh hands on minds on activity terhadap hasil belajar siswa melalui model pembelajaran inkuiri terbimbing. Desain penelitian yang digunakan adalah oneshot case study, dengan populasi seluruh siswa kelas IX SMPS Methodist Tanjung Morawa Tahun Ajaran 2017/2018. Sampel penelitian adalah siswa kelas IX-3 yang diambil dengan teknik Cluster Random Sampling. Berdasarkan hasil uji regresi linear sederhana diperoleh kesimpulan bahwa terdapat pengaruh positif dan signifikan antara hands on minds on activity terhadap hasil belajar fisika siswa dalam ranah kognitif melalui model pembelajaran inkuiri terbimbing. Besarnya pengaruh hands on minds on activity terhadap hasil belajar siswa dalam ranah kognitif melalui model pembelajaran inkuiri terbimbing sebesar $68,2 \%$.
\end{abstract}

Kata kunci : hands on minds on activity, hasil belajar, strategi pembelajaran inkuiri terbimbing

\section{A. PENDAHULUAN}

Berdasarkan hasil wawancara dengan guru mata pelajaran Fisika di SMAS Methodist Tanjung Morawa, diperoleh bahwa: (1) Pembelajaran fisika kurang diminati oleh siswa karena fisika dianggap sulit, (2) Kurangnya kesempatan siswa untuk memiliki pengalaman belajar aktif, (3) Kegiatan demonstrasi dan praktikum sederhana dalam pembelajaran jarang dilaksanakan sehingga aktifitas fisik dan psikis (hands on minds on activity) siswa tidak terbentuk, (4) Hasil belajar siswa pada mata pelajaran fisika banyak yangbelum mencapai Kriteria Kelulusan Minimal dengan standar nilai 75 yang telah ditetapkan disekolah. Rendahnya ketuntasan hasil belajar tersebut diduga siswa belum memahami konsep fisika dari materi yang diajarkan, sehingga hasil belajarnya pun tidak optimal.

Aini Khurrotul dan Kusumawati D.

2014. Penerapan Model Pembelajaran Inkuiri denganHands On Minds On Activity untuk meningkatkan Hasil Belajar Siswa Pada Materi Pokok Termokimia. menyatakan bahawa hasil belajar siswa lebih maksimal menggunakan model pembelajaran inkuiri.

Penelitian ini bertujuan untuk mengetahui pengaruh Hands On Minds On Activity terhadap hasil belajar siswa melalui model pembelajaran inkuiri terbimbing Kartono. 2011. Hands On Activity Pada Pembelajaran Geometri Sekolah Sebagai Asesmen Kinerja Siswa menyatakan bahwa nilai kinerja siswa pada pembelajaran geometri lebih baik daripada model kontektual

Hands on mind on activity adalah suatu kegiatan yang melibatkan praktik atau eksperimen dengan menggunakan peralatan dan bahan yang berlaku. Kartono (2011) menjelaskan bahwa hands on activity adalah suatu kegiatan yang dirancang untuk melibatkan siswa dalam menggali informasi dan bertanya, beraktivitas dan menemukan, mengumpulkan data dan menganalisis serta membuat kesimpulan sendiri.

Hasil belajar menurut Suprijono dalam Thobroni (2015) adalah pola- pola perbuatan, nilai-nilai, pengertian-pengertian, sikap-sikap, apresiasi, dan ketrampilan. Inkuiri menurut Suryani (2012) berasal dari kata to inquire yang berarti ikut serta, atau terlibat dalam mengajukan pertanyaan-pertanyaan, mencari informasi, dan melakukan penyelidikan to inquire yang berarti ikut serta, atau terlibat dalam mengajukan pertanyaan-pertanyaan, mencari informasi, dan melakukan penyelidikan. 
Hal : $11-13$

\section{B. METODE}

Dalam penelitian ini terdapat dua bentuk variabel yaitu variabel bebas dan variabel terikat. Variabel bebas dalam penelitian ini adalah hands on minds on activity (X) sedangkan variabel terikatnya adalah hasil belajar siswa (Y). Serta strategi pembelajaran inkuiri terbimbing sebagai variabel moderator (Z). Untuk mendapatkan gambaran yang jelas tentang pengaruh variabel bebas terhadap variabel terikat, maka dapat dijelaskan dengan paradigma pemikiran seperti pada Gambar 1. Bentuk Kerangka Konseptual.

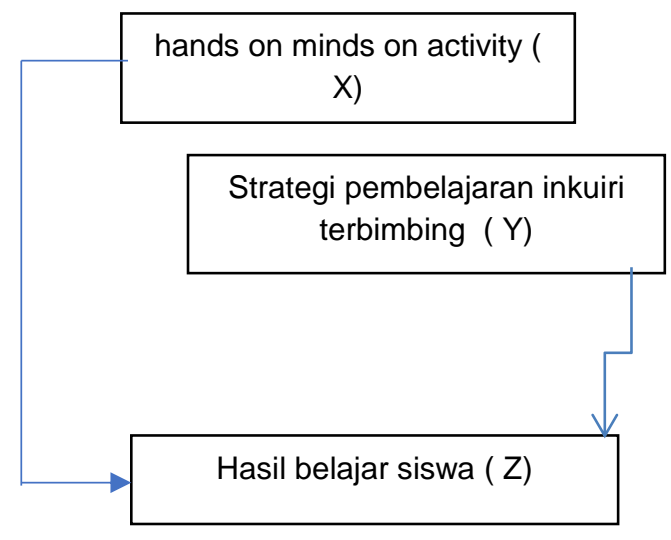

Gambar 1. Kerangka Konseptual

Analisis instrumen menggunakan uji validitas dan uji reliabilitas dan pengujian hipotesis menggunakan metode analisis dengn program komputer SPPS 20 yaitu : uji normalitas, uji linearitas, uji korelasi dan uji regresi linier sederhana.

\section{HASIL DAN PEMBAHASAN}

Tabel 1. Reliability Statistics

\begin{tabular}{|l|l|}
\hline Cronbach's Alpha & $\mathrm{N}$ of Items \\
\hline
\end{tabular}

,863

Sumber : Hasil Pengolahan SPSS Versi 20 (2017) Hasil output SPSS diketahui nilai reabilitas sebesar 0,863 > 0,6 (Nunnally,1960 dan Ghazali, 2006). Hasil uji validitas dan reabilitas sudah memadai maka instrumen dapat dipercaya untuk digunakan dalam penelitian.

Tabel 2. ANOVA ${ }^{a}$

\begin{tabular}{|l|r|r|r|r|l|}
\hline Model & \multicolumn{1}{|c|}{$\begin{array}{c}\text { Sum of } \\
\text { Squares }\end{array}$} & Df & $\begin{array}{c}\text { Mean } \\
\text { Square }\end{array}$ & F & Sig. \\
\hline Regression & 316,168 & 2 & 153,084 & 55,152 &, $000^{\mathrm{b}}$ \\
1 Residual & 199,112 & 73 & 1,904 & & \\
Total & 525,280 & 75 & & & \\
\hline
\end{tabular}

a. Dependent Variable: HASIL_BELAJAR)

b. Predictors: (Constant),

HANDS_ON_MINDS_ON_ACTIVITY,

STRATEGI_PEMBELAJARAN_INKUIRI_TERBIMBING)

Berdasarkan Tabel 2. diatas bahwa uji Anova atau Uji $F$ menghasilkan nilai $F$ hitung sebesar $F$ hitung $(55,152)>F$ tabel $(2,93)$ dan probabilitas signifikan jauh lebih kecil dari 0,005 yaitu $0,000<0,05$ maka model regresi dapat dikatakan bahwa hands on minds on activity dan strategi pembelajran inkuiri terbimbing berpengaruh secara serempak (simultant) terhadap .hasil belajar siswa. Dengan demikian hipotesis sesudahnya $\left(\mathrm{H}_{1}\right)$ diterima. 
Hal : $11-13$

Tabel 3. Model Summary

\begin{tabular}{|c|c|c|c|c|}
\hline Model & $\mathrm{R}$ & $\begin{array}{c}\mathrm{R} \\
\text { Square }\end{array}$ & $\begin{array}{c}\text { Adjusted } \\
\mathrm{R} \text { Square }\end{array}$ & $\begin{array}{c}\text { Std. Error } \\
\text { of the } \\
\text { Estimate }\end{array}$ \\
\hline 1 &, $781^{\mathrm{a}}$ &, 709 &, 682 & 1,704 \\
\hline
\end{tabular}

Berdasarkan Tabel 3 diperoleh bahwa angka Adjusted $\mathrm{R}$ Square 0,598 yang dapat disebut koefisien determinas yang dalam hal ini berarti $59,8 \%$ hasil belajar dapat diperoleh dan dijelaskan oleh strategi pembelajaran sedangkan sisanya $(100 \%-68,2 \%=31,8 \%)$ dijelaskan oleh pengaruh faktor lain atau variabel diluar model.

\section{DAFTAR PUSTAKA}

Aini Khurrotul dan Kusumawati D. 2014. Penerapan Model Pembelajaran Inkuiri dengan Hands On Minds On Activity untuk meningkatkan Hasil Belajar Siswa Pada Materi Pokok Termokimia. Jurnal Pendidikan Kimia.Vol.3(1),99-105

Cleaver,Samatha.2012. Hands-On-Is-MindsOn.Artikel.

http://www.scholastic.com/browse/article.jsp? id=3751901. Diakses Tanggal 20 Mei 2017

Kartono. 2011. Hands On Activity Pada Pembelajaran Geometri Sekolah Sebagai Asesmen Kinerja Siswa. Jurnal Pendidikan Matematika. Vol. 3 (2), 21-32)

Retnosari, Gesty. 2015. Pengembangan LKS Berbasis Inkuiri Terbimbing Pada Materi Suhu dan Perubahannya.Jurnal Pembelajaran Fisika.Vol.3(3),97-108

Sanjaya, Wina. 2012. Media Komunikasi Pembelajaran. Jakarta: Kencana Prenada Media Group

Thobroni M. 2015. Belajar \& Pembelajaran Teori dan Praktik.Yogyakarta: Ar-Ruzz Media.

Trihendradi, Cornelius. 2015. Langkah Mudah Menguasai SPSS 20.Yogyakarta: Penerbit Andi 